\title{
A New Small-Bodied Species of Bavayia (Reptilia: Squamata: Diplodactylidae) from Southeastern New Caledonia ${ }^{1}$
}

\author{
Aaron M. Bauer, ${ }^{2,3}$ Todd R. Fackman, ${ }^{3}$ Ross A. Sadlier, ${ }^{4}$ Glenn Shea,${ }^{5}$ and Anthony H. Whitaker ${ }^{6}$
}

\begin{abstract}
A new species of diplodactylid genus Bavayia, B. goroensis, is described from the Plaine des Lacs region of the Province Sud, New Caledonia. The new gecko is the smallest member of the Bavayia cyclura clade (49 mm snout-vent length) and, based on a molecular phylogeny, is basal within this group. It differs from other members of this group in its much smaller size, more gracile body, and lower number of precloacal pores and subdigital lamellae. The new species is known from only two locations, one of which is adjacent to extensive nickel mining operations. Because of its limited distribution and the direct and indirect threats posed by the proximity of mining to one of the populations, the species is here regarded as "Endangered."
\end{abstract}

Diplodactylid geckos are represented in New Caledonia by five genera, all endemic. The most speciose of these is Bavayia Roux, which is composed of relatively nondescript species with mostly plesiomorphic features. Recent molecular phylogenetic analyses of the New Caledonian geckos have revealed that members of the Bavayia validiclavis group do not constitute part of the monophyletic

${ }^{1}$ This research was supported by grants DEB 0108108 and DEB 0515909 from the National Science Foundation to A.M.B. and T.R.J. Fieldwork was carried out under contracts AMBS-200313 between the Australian Museum Business Services (AMBS) and Goro Nickel (GNi) and C-286-06 between Whitaker Consultants Limited (WCL) and the Direction des Ressources Naturelles (DRN). Manuscript accepted 7 August 2007.

${ }^{2}$ Corresponding author: (phone: 610-519-4857; fax: 610-519-7863; e-mail: aaron.bauer@villanova.edu).

${ }^{3}$ Department of Biology, Villanova University, 800 Lancaster Avenue, Villanova, Pennsylvania 190851699 (e-mail: aaron.bauer@villanova.edu [Bauer], todd .jackman@villanova.edu [Jackman]).

${ }^{4}$ Department of Herpetology, Australian Museum, 6 College Street, Sydney 2000, New South Wales, Australia (e-mail: ross.sadlier@austmus.gov.au).

${ }^{5}$ Faculty of Veterinary Science, University of Sydney, Sydney 2006, New South Wales, Australia (e-mail: gshea@mail.usyd.edu.au).

${ }^{6}$ Whitaker Consultants, 270 Thorpe-Orinoco Road, Orinoco, R.D. 1, Motueka 7196, New Zealand (e-mail: whitaker@ts.co.nz).

Pacific Science (2008), vol. 62, no. 2:247-256

(C) 2008 by University of Hawai'i Press

All rights reserved group that includes the other species traditionally assigned to Bavayia, and a new genus, Dierogekko, has been erected to accommodate $B$. validiclavis Sadlier and its seven newly discovered congeners (Bauer et al. 2006). As currently construed, Bavayia comprises 11 species (Bauer and Sadlier 2000), but ongoing phylogenetic analyses and attendant taxonomic revision suggest that there may be as many as 40 diagnosably distinct and largely geographically isolated species-level taxa within the group (Bauer and Jackman 2006). Most of the undescribed species belong to one of several species complexes that have been proposed on morphological grounds (Roux 1913, Bauer 1990, Bauer and Sadlier 1993, Wright et al. 2000) and subsequently confirmed using DNA sequence-based phylogenetic analysis. The most genetically diverse of these species groups is the Bavayia cyclura group, which currently includes the described species B. cyclura (Günther), B. montana Roux, $B$. crassicollis Roux, and B. robusta Wright, Bauer \& Sadlier. The content of this group is expected to increase three- or fourfold, however, when all identified lineages are formally described. Taxa in the cyclura group share the presence of both medial and lateral apical scansors on digit I and two or three rows of precloacal pores in males. All described and most undescribed species in this clade are moderate- to large-bodied (72-86 $\mathrm{mm}$ maximum snout-vent length) and share a very similar overall appearance. We here 
describe a distinctive member of this group, characterized by a small, slender body, from southern New Caledonia.

\section{MATERIALS AND METHODS}

\section{Morphology}

Specimens from the collections of the Australian Museum (AMs), California Academy of Sciences (CAs), and Muséum National d'Histoire Naturelle, Paris (MNHN) were examined under a dissecting microscope. The following measurements were taken with digital calipers (to the nearest $0.1 \mathrm{~mm}$ ): snout-vent length ([SVL] from tip of snout to vent), trunk length ([TrunkL] distance from axilla to groin measured from posterior edge of forelimb insertion to anterior edge of hindlimb insertion), crus length ([CrusL] from base of heel to knee), tail length ([TailL] from vent to tip of tail), tail width ([TailW] measured at widest point of tail), head length ([HeadL] distance between retroarticular process of jaw and snout tip), head width ([HeadW] maximum width of head), head height $([\mathrm{HeadH}]$ maximum height of head, from occiput to underside of jaws), ear length ([EarL] longest dimension of ear), forearm length ([ForeaL] from base of palm to elbow), orbital diameter ([OrbD] greatest diameter of orbit), nares to eye distance ([NarEye] distance between anteriormost point of eye and nostril), snout to eye distance ([SnEye] distance between anteriormost point of eye and tip of snout), eye to ear distance ([EyeEar] distance from anterior edge of ear opening to posterior corner of eye), internarial distance ([Internar] distance between nares), and interorbital distance ([Interorb] shortest distance between left and right supraciliary scale rows). Unless otherwise stated, counts and measurements were made on right side of specimens.

Preserved specimen photographs were taken with a digital camera. Radiographic observations were made using a closed-cabinet $\mathrm{x}$-ray system.

\section{Molecular Methods and Phylogenetic Analyses}

Genomic DNA was extracted from $95-100 \%$ ethanol-preserved liver samples using a tissue kit (Qiagen QIAmp, Valencia, California). We used a double-stranded polymerase chain reaction to amplify 1,464 aligned bases of the mitochondrial gene ND2 using previously published primers (Bauer et al. 2006). Purified sequencing reactions were analyzed on an automated sequencer (ABI 3700). To ensure accuracy, negative controls were included in every reaction, complementary strands were sequenced, and sequences were manually aligned by eye using the original chromatograph data in the program SeqMan II. All sequences will be deposited in the GenBank database, and those derived from the new species described here are accessioned there as EU054303-EU054304.

Phylogenetic trees were estimated using maximum parsimony in PAUP* $4.0 \mathrm{~b} 10 \mathrm{a}$ (Swofford 2002). The heuristic search algorithm was used with the following conditions: 25 random addition replicates, tree bisectionreconnection (TBR) branch swapping, and gaps treated as missing data. We used nonparametric bootstraps (1,000 pseudoreplicates) to assess node support in resulting topologies.

\section{RESULTS}

\section{Systematics}

Bavayia goroensis Bauer, Jackman, Sadlier, Shea \& Whitaker, n. sp.

Figures 1-5

TYPE MATERial: All collected in the Grand Sud, Province Sud, New Caledonia. Holotype: MNHN 2004.0027 (formerly aMs R166017), Plaine des Lacs, route de la Wajana, $22^{\circ} 16^{\prime} 26^{\prime \prime} \mathrm{S}, 166^{\circ} 57^{\prime} 43^{\prime \prime} \mathrm{E}$, collected by R. Sadlier and G. Shea, 11 December 2003. Paratypes: ams R166030, Plaine des Lacs, route de la Wajana, Province Sud, $22^{\circ} 16^{\prime} 35^{\prime \prime} \mathrm{S}, 166^{\circ} 57^{\prime} 38^{\prime \prime} \mathrm{E}$, collected by R. Sadlier and G. Shea, 10 December 2003; CAS 235383 (formerly aMs R167422), $3.0 \mathrm{~km}$ southeast of Ka Yé Wagwé, Plaine des Lacs, $22^{\circ} 13^{\prime} 22.03^{\prime \prime} \mathrm{S}, 166^{\circ} 54^{\prime} 33.04^{\prime \prime} \mathrm{E}$, collected by A. H. Whitaker and R. A. Sadlier, 7 February 2007; AMs R167433, $1.8 \mathrm{~km}$ southeast of Ka Yé Wagwé, Plaine des Lacs, 22 ${ }^{\circ} 13^{\prime}$ 


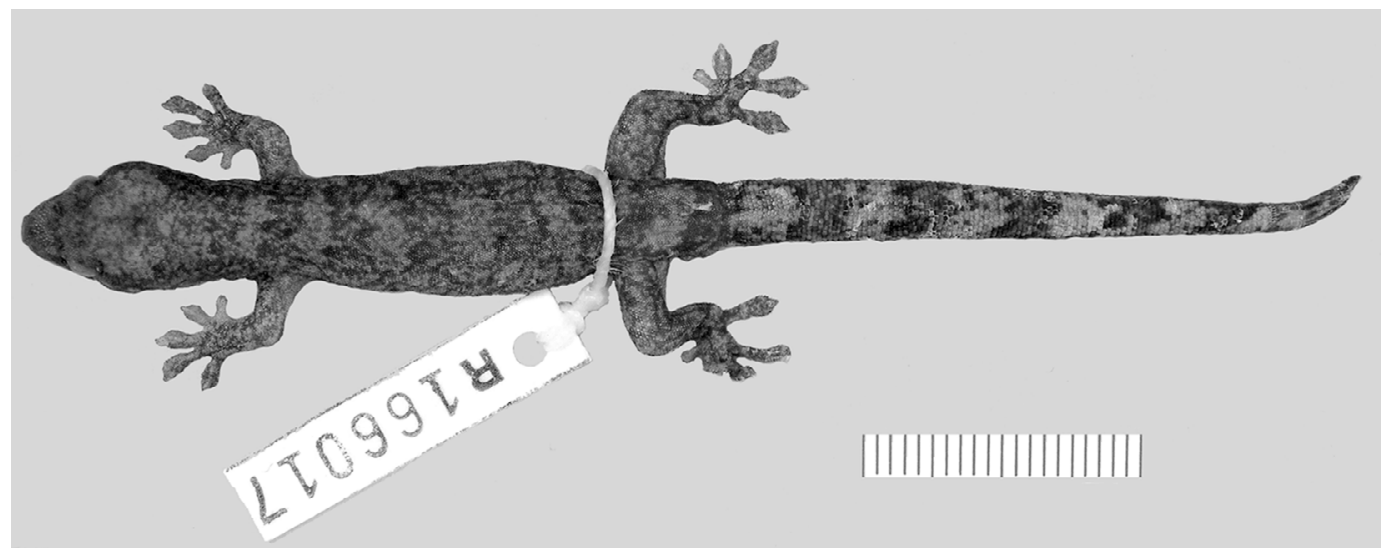

FigURE 1. Holotype of Bavayia goroensis (MNHN 2004.0027). Scale bar $=20 \mathrm{~mm}$.

$04.59^{\prime \prime} \mathrm{S}, 166^{\circ} 54^{\prime} 01.49^{\prime \prime}$ E, collected by A. H. Whitaker and R. A. Sadlier, 11 February 2007.

ETYMology: The specific epithet goroensis refers to the Goro nickel mine site in the southeastern Grande Terre of New Caledonia, the area from which the type specimens were collected.

DIAGNOSIs: Bavayia goroensis is a smallsized $(<49 \mathrm{~mm}$ SVL for the three known adults), slender-bodied member of its genus. It may be distinguished from the superficially Bavayia-like Oedodera marmorata Bauer, Jackman, Sadlier \& Whitaker in possessing divided distal subdigital lamellae and in lacking a swollen neck and medial apical scansors on digit II of the pes, and from Dierogekko in its dorsal pattern of transverse markings (versus longitudinally striped or patternless). Among congeners it may be distinguished from $B$. sauvagii (Boulenger), B. ornata Roux, and $B$. madjo Bauer, Jones \& Sadlier by the position of the claw on digit I between two apical scansors (versus lateral to a single apical scansor), and from B. geitaina Wright, Bauer \& Sadlier, B. septuiclavis Sadlier, B. pulchella Bauer, Whitaker \& Sadlier, and B. exsuccida Bauer, Whitaker \& Sadlier by its two (versus one) rows of precloacal pores. Bavayia goroensis is much smaller than all other members of the B. cyclura group (maximum $47 \mathrm{~mm}$ versus $\geq 72 \mathrm{~mm}$ maximum SVL) and has a lower number of precloacal pores (12 [anterior row] $/ 4-5$ [posterior row] versus 10-18/ $8-14$ in $B$. crassicollis, $12-21 / 8-14$ in $B$. cyclura, 19-27/6-13 in B. montana, 14-21/413 in B. robusta) and usually has a lower number of lamellae beneath digit IV of the pes (12 versus $12-16$ in all others). It is further distinguished from B. cyclura and B. crassicollis by having the postmentals in contact posteriorly (versus separated by the mental).

DESCRIPTION: (data from adult male holotype, MNHN 2004.0027). Body slender, depressed. Head triangular with a blunt snout, large (HeadL $=29 \%$ SVL), moderately wide $($ HeadW $=63 \%$ HeadL), and depressed $(\mathrm{HeadH}=36 \%$ HL), clearly demarcated from neck; interorbital/frontal region somewhat depressed, nasal region with a distinct, shallow indentation; canthus weakly inflated; snout relatively short (SnEye $=33 \%$ HeadL), longer than eye diameter $(\mathrm{OrbD}=76 \%$ SnEye). Scales on dorsum of snout approximately two to three times the diameter of those on occipital region, becoming larger on lateral surfaces of snout and in first 1-2 rows of scales posterior to supranasals. Eye large $(\mathrm{OrbD}=25 \%$ HeadL); pupil oval, margins crenellated. Ear opening approximately 1.5 times wide as high, obliquely oriented; eye to ear distance only slightly longer than diameter of eyes (EyeEar $=104 \%$ OrbD). Rostral rectangular, broader $(2.3 \mathrm{~mm})$ than 


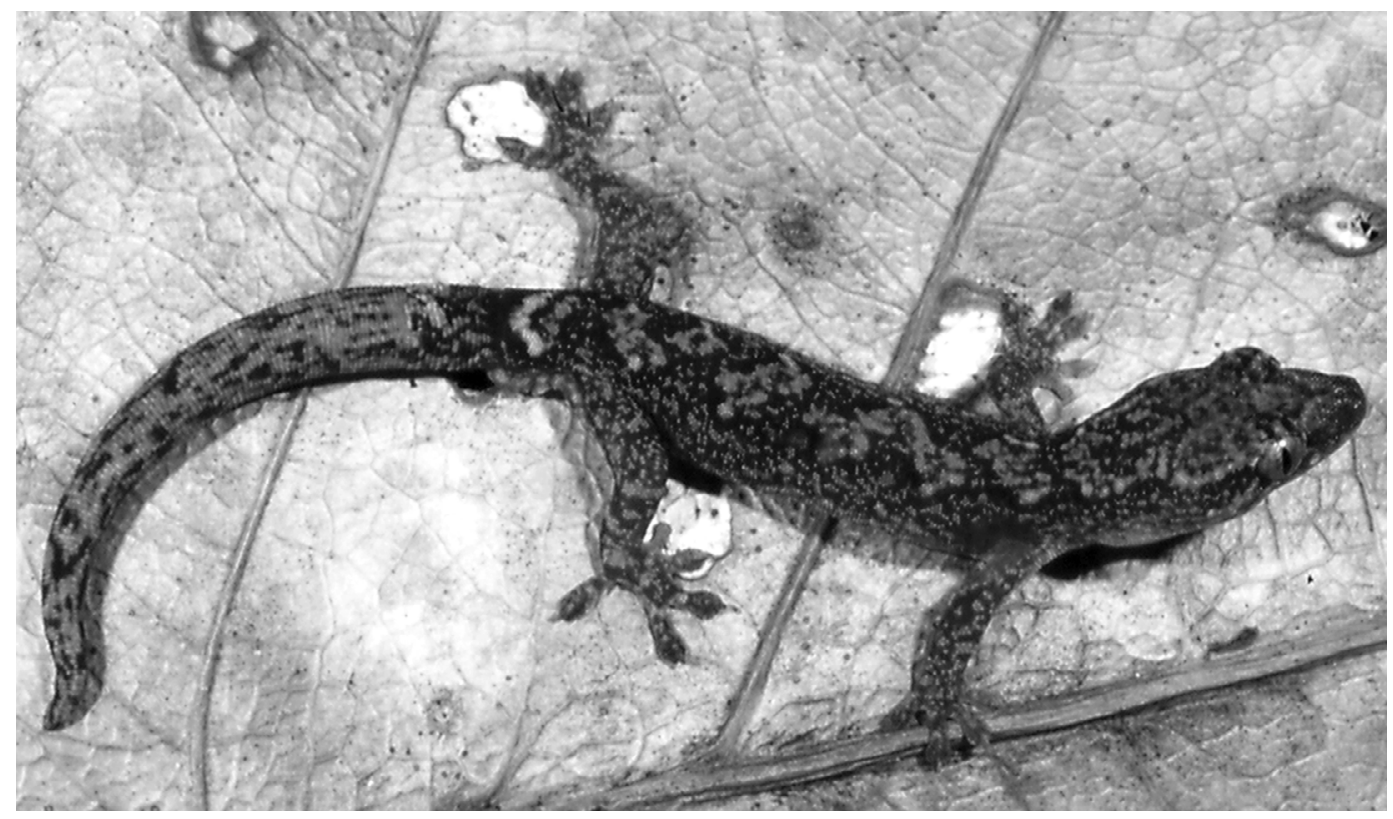

Figure 2. Photograph of adult male paratype (ams 166030) of Bavayia goroensis in life. Note the highly asymmetrical dorsal pattern and near confluence of pale markings.

high $(1.2 \mathrm{~mm})$, divided dorsally by a short rostral crease, contacted posteriorly by 1 large hexagonal internasal and 2 large supranasals, each approximately two-thirds size of internasal, contacted laterally by first supralabial. Nostrils rounded, laterally oriented, surrounded by rostral, 3 postnasals (ventralmost smallest), and first supralabial. Mental triangular, breadth approximately same as depth $(1.3 \mathrm{~mm})$. First two infralabials elongate; first infralabials in broad contact with one another posterior to mental scale, bordered posteriorly by 2 rows of enlarged chin scales, each four to five times size of gular granules. Scales in 2-3 rows medial to infralabials somewhat enlarged and elongate. Ten (left) or 11 (right) enlarged supralabial scales, posteriormost only about three times size of rictal scales, 7 (left) or 8 (right) supralabials to midpoint of orbit; 10 (left)-9 (right) enlarged infralabial scales; 33 scale rows between supraciliaries, 10 scale rows across frontal bones at midpoint of orbit.

Dorsal scales tiny, homogeneous, granular; ventral scales two to three times diameter of dorsals, smooth, flattened, juxtaposed to subimbricate, enlarged in precloacal region and on base of thighs. Posterior abdominal scales rounded, midabdominal scales slightly elongate. Approximately 122 scale rows around midbody. No ventrolateral skin folds. Scales of limbs slightly larger than dorsals. Scales on palms and soles smooth, flattened. Foreand hindlimbs short and thick (ForeaL/SVL ratio 0.12; CrusL/SVL ratio 0.15), axillary pocket weakly developed. Digits short, all bearing claws, those on digit I of both manus and pes reduced and partially sheathed, remaining claws short but robust and strongly recurved; relative length of digits of manus: $\mathrm{IV} \sim \mathrm{III}>\mathrm{V}>\mathrm{II}>\mathrm{I}$, and of pes: $\mathrm{IV}>\mathrm{V} \sim \mathrm{III}>$ II $>$ I; digits moderately webbed, especially between digits III and IV of pes and III, $\mathrm{IV}$, and $\mathrm{V}$ of manus; digits III and IV of pes tightly bound along length of elongate metatarsals. Subdigital lamellae of digits II-V unpaired basally, completely divided (occasionally fragmented into 2 scales) beneath widest portion of pad, lateral margins of lamellae angled distally, distalmost scansor 
undivided; all lamellae of digit I unpaired. Claw of digit I, manus and pes, lies between a smaller lateral and a larger (twice size of lateral) medial apical scansor. Lamellar counts (including all scales more than twice size of scales at base of digits) from right (and left) sides 6-9-11-11-10 (5-9-11-11-11) manus and 6-10-10-12-11 (6-11-10-12-11) pes (excludes apical scansors of digit I).

Moderate-sized precloacal pores in slightly enlarged scales, arranged in an anterior row of 12 pores (6 left, 6 right) and a posterior row of 5 pores (3 left, 2 right) with a single poreless scale separating left and right series in both rows. No femoral pores or enlarged femoral scales. Hemipenial bulge large; cloacal spurs on raised base just posterior to hindlimb insertion, with 1 (right) or 2 (left) enlarged, smooth, laterally compressed scales. Mostly original tail (approximately 17\% regenerated in holotype) $113 \%$ of SVL, thick, roughly round in cross section. Dorsal caudal scales small, flat, juxtaposed to weakly subimbricate, squarish with rounded free margins, arranged in regular rows. Surface of tail very weakly segmented, caudal scale rows forming whorls, each whorl 5-6 dorsal scale rows and 4-5 ventral scale rows long; midventral caudal scales not enlarged. Scales of pygal region smaller than those of postpygal region. Scales of regenerated portion of tail slightly irregular in shape; distal subcaudals bearing adhesive setae.

Color in preservative (based on holotype): Dorsum a mottled medium brown with a series of beige to light brown transversely oriented bands or blotches. Both pale bands and darker interspaces mottled dorsally and indistinct on flanks. Pale, mottled markings of crown partly continuous with pale nape band; 1 pale marking at level of forelimb insertion, 4 between level of axilla and groin, 1 over posterior portion of sacrum and pygal portion of tail. Snout mid- to dark brown anteriorly, becoming a mottled light brown in the frontal region. Crown beige with faint, darker irregular reticulations. A brown stripe, darkest anteriorly, in the loreal region, passing through orbit to above ear and continuous with nape band. An irregular, transverse dark brown band across dorsum of head at level of anterior margin of orbits. Labials with whitish central spots and brown dorsal borders. Limbs mottled light and dark brown with manus and pes, especially toes, chiefly beige; irregular darker bands across base of digits. Postpygal portion of tail with 6 irregular cream to off-white chevrons or bands alternating with brown, both light and dark bands mottled and diffuse laterally; posteriorly, a series of three dark blotches on a cream to beige middorsal stripe. Venter cream with tiny flecks of brown, particularly along lateral margins and under throat, limbs, and precloacal area. Tail venter cream to beige with dark speckling on most scales.

Color in life (based on photographs of all three paratypes in life Figures 2-3): Dorsum chocolate brown with minute yellow speckles producing mottled appearance. Dorsal markings pale purplish white, cream to white at lateral margins. Chevrons or bands on proximal portion of tail bright white. Iris coppery. Venter pale yellow.

osTEOLOGY: Vertebral counts are typical for diplodactylid geckos, with 26 presacral and 2 sacral vertebrae. The first three cervical vertebrae are without ribs, as is the last presacral (lumbar) vertebra. The caudal skeleton includes 5 pygal vertebrae and 16.5 postpygals anterior to the regenerated portion of the tail in the holotype. AMs 166030 has 2.5 postpygals in the original portion of the tail. Frontal single, parietals paired, stapes imperforate. Eleven premaxillary teeth and approximately 30 maxillary teeth on each side in the paratype, which was fixed with the jaws open. The phalangeal formulas of the manus and pes are unreduced, 2-3-4-5-3 and 2-3-4-5-4, respectively. A single pair of slender crescentic cloacal bones is present in both specimens at the level of the second postpygal vertebra.

Variation: Mensural data for the type series are presented in Table 1 . The paratypes agree with the holotype in most aspects. Differing conditions follow: internasal and supranasals subequal, first infralabials separated posteriorly by an elongate, hexagonal postmental (AMs R 167433); internasal twothirds size of supranasals, only two enlarged postnasals on each side, first infralabials sepa- 


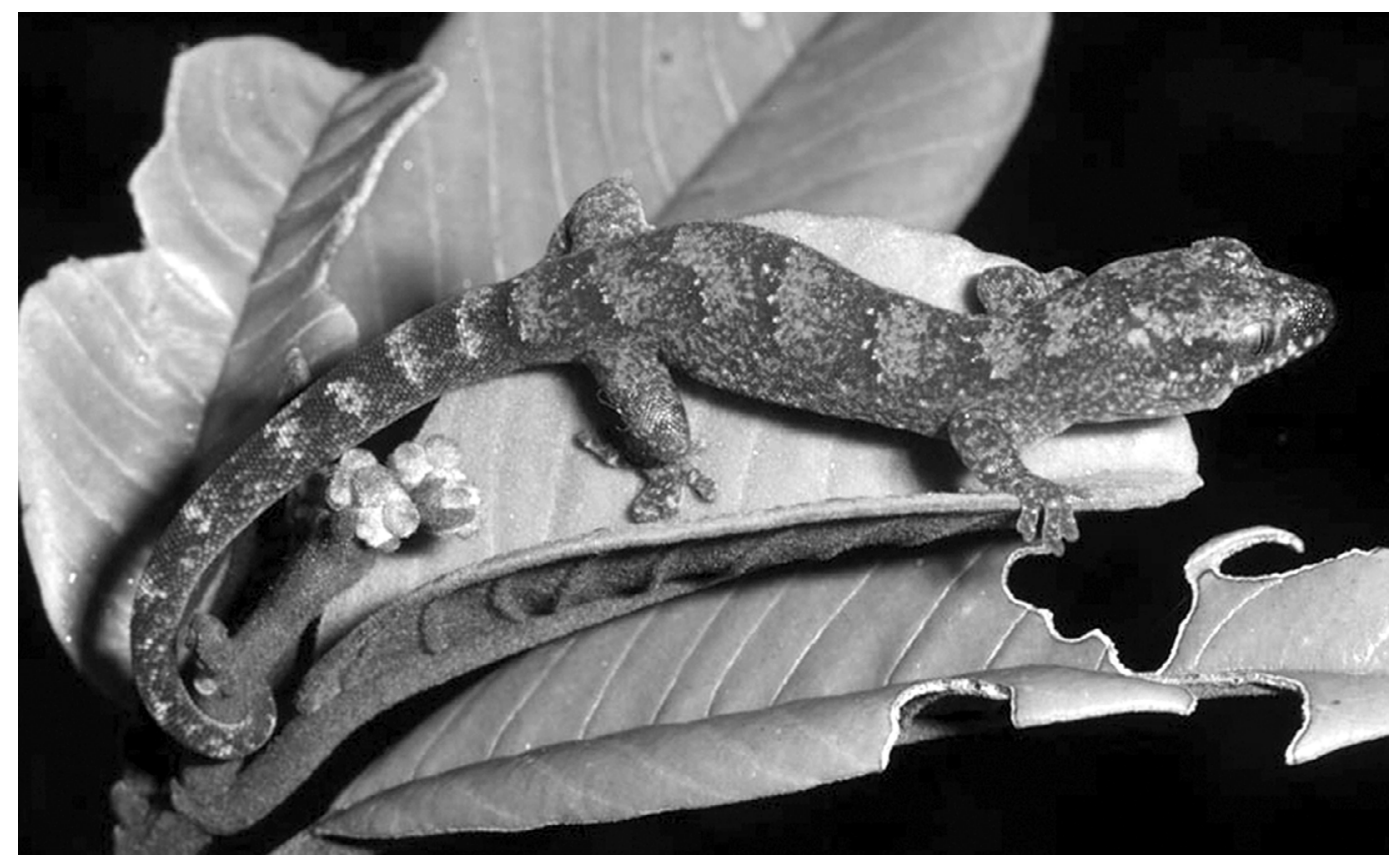

Figure 3. Photograph of juvenile male paratype (cas 235383) of Bavayia goroensis in life. Note the bold pattern and presence of small bright white spots on the head and body dorsum.

TABLE 1

Mensural Data for the Types of Bavayia goroensis, n. sp.

\begin{tabular}{lcccc}
\hline \hline Character & MNHN 2004.0027 holotype & AMs R 166030 paratype & AMs R 167433 paratype & CAs 235383 paratype \\
\hline Sex & Male & Male & Female & Juvenile male \\
SVL & 46.4 & 46.3 & 48.6 & 33.7 \\
ForeaL & 5.7 & 5.6 & 6.0 & 3.8 \\
CrusL & 6.9 & 6.5 & 6.8 & 4.4 \\
TailL & $52.5(8.7$ regen.) & $42.7(33.6$ regen.) & $42.2(28.0$ regen.) & 34.3 \\
TailW & 4.1 & 4.5 & 4.0 & 3.1 \\
TrunkL & 20.6 & 20.0 & 22.4 & 14.7 \\
HeadL & 13.5 & 12.8 & 13.1 & 10.6 \\
HeadW & 8.6 & 8.5 & 8.9 & 6.4 \\
HeadH & 4.8 & 5.2 & 5.1 & 3.6 \\
OrbD & 3.4 & 3.5 & 3.3 & 1.8 \\
EyeEar & 3.5 & 4.1 & 3.9 & 3.7 \\
SnEye & 4.4 & 4.7 & 4.9 & 3.2 \\
NarEye & 3.2 & 3.2 & 3.2 & 3.6 \\
Interorb & 4.5 & 4.7 & 4.4 & 0.8 \\
EarL & 1.7 & 1.3 & 1.3 & 1.2 \\
Internar & 1.2 & 1.6 & 1.6 & . \\
\hline
\end{tabular}

Note: See Variation section for discussion of meristic variation. Abbreviations as in Materials and Methods. All measurements in $\mathrm{mm}$. 


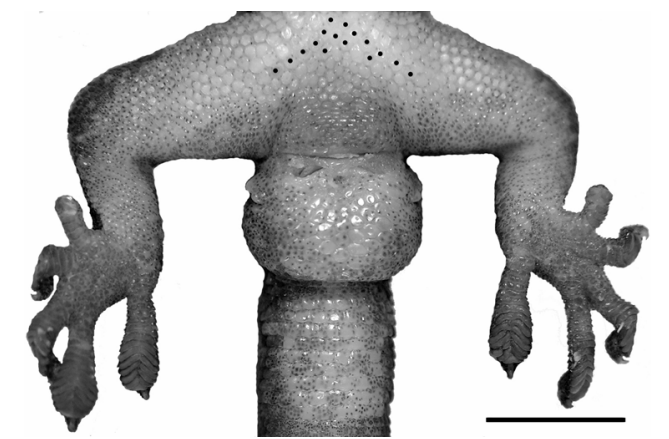

Figure 4. Ventral view of adult male paratype (AMs 166030) of Bavayia goroensis illustrating precloacal pore arrangement (pores indicated by black dots). Scale bar $=5 \mathrm{~mm}$.

rated posteriorly by an enlarged hexagonal postmental (CAs 235383); enlarged central internasal separated from supranasals by a longitudinally oriented pair of small internasals on each side such that three internasals in total contact the rostral (ams R 166030). Precloacal pores in an anterior row of 12 (six left, six right) and a posterior row of four (two left, two right, with a single poreless scale separating the two pores on the left side) (aMs R 166030 [Figure 4]) or in continuous rows of 12 (anterior) and five (posterior) (CAs 235383); absent in female paratype. Lamellar counts from right (and left) sides of manus and pes: AMs R 166030: 5-9-10-11-10 (5-9-10-10-9) and 6-10-11-10-9 (5-8-10-1110), AMs R 167433: 5-9-10-11-11 (5-9-1112-11) and 6-10-12-13-11 (5-10-10-12-10), CAS 2353 83: 5-8-10-11-10 (5-9-11-12-10) and 6-9-11-13-10 (6-9-11-12-11). Female paratype contains two large oviductal eggs. Juvenile paratype with original tail with flattened tip bearing a small subcaudal scansorial pad.

Female paratype (ams R 167433) similar to holotype in coloration except crown more heavily mottled with dark blotches and speckles and three pale bands anterior to hindlimb insertion strongly asymmetrical and diffuse laterally, contiguous with ventrolateral speckling. Dorsum of ams R 166030 (Figure 2) mottled chocolate brown with middorsal cream blotches largely asymmetrical, extending more or less continuously from crown to pygal portion of tail, where a broad, symmetrical, white chevron is present. Posterior margin of each pale marking outlined by a thick, dark brown line. Speckling of flanks extending high on to dorsum. Limbs mottled but generally darker brown than those of holotype. Tail mostly regenerated, beige, becoming darker laterally, with dark brown, mostly longitudinally oriented, dashes and blotches. Juvenile (CAs 235383 [Figure 3]) particularly boldly patterned, each pale dorsal marking, including those on crown and nape, discrete and separate from others. Small bright white spots forming more or less transverse lines across snout and interorbital region and also present behind each of the pale dorsal markings except those on crown and nape. Labials and area above orbits cream. Iris silvery in life.

\section{Distribution and Habitat}

Bavayia goroensis is known only from two areas on the Plaine des Lacs, in the Province Sud of New Caledonia-one on the Goro Plateau just southeast of the Grand Lac and one just east of Chutes de la Madeleine (Figure 5). On the Goro Plateau it was recorded from two nearby sites (as Bavayia sp. [see Sadlier and Shea 2004]), each representing a different type of canopied maquis-maquis arbustif (AMS R166030) and maquis paraforestier (MNHN 2004.0027). The maquis arbustif site had a mosaic of dense and open vegetation, the open areas having a sparse to moderate groundcover of shrubs, and the more closed-in areas had a moderately dense canopy but fewer understory shrubs and relatively thicker leaf litter and debris coverage on the ground. The gecko collected in this habitat was found active at 2100 hours on a low dead tree branch $(5 \mathrm{~cm}$ diameter), approximately $1 \mathrm{~m}$ above the ground. The maquis paraforestier site (Figure 6) is unusual in being characterized by tall, forestlike maquis dominated by Gymnostoma L. A. S. Johnson and Metrosideros Banks ex Gaertner and having a relatively open understory. The holotype was collected during daylight from 


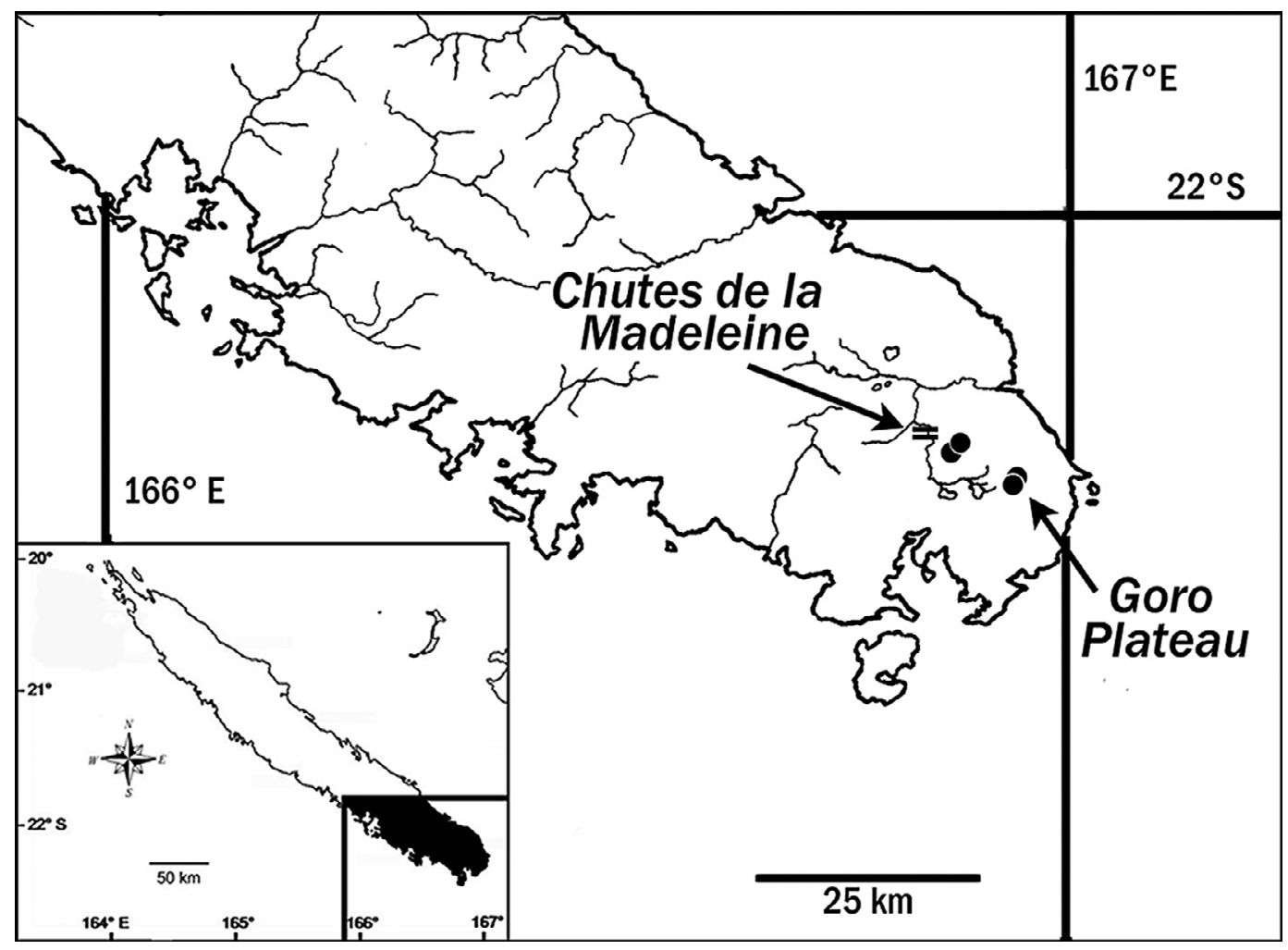

Figure 5. Map of the Plaine des Lacs region, Province Sud, New Caledonia, showing the localities where Bavayia goroensis has been collected.

under the peeling bark of a sapling. Maquis paraforestier is of particular conservation value in the region because it may act as a partial corridor for long-term migration of moist-forest-dependent species between larger blocks of isolated closed forest. East of the Chutes de la Madeleine B. goroensis was recorded from two nearby sites, one a moderately dense and tall maquis shrubland adjacent to a small patch of humid forest at the base of a range of hills (CAS 235383), and the other on low open maquis with scattered Gymnostoma on a level plain between the Ka Yé Wagwé range and the extensive reed beds bordering the northern shores of Lac en Huit and Grand Lac (ams R167433). Both of these specimens were found active at night; the former specimen was collected at 2122 hours in foliage of the crown of a small-leaved maquis shrub $(1.8 \mathrm{~m})$ and the latter was located at 2240 hours in the crown of a $4.0 \mathrm{~m}$ tall Gymnostoma sp.

The new species was found with its congener B. septuiclavis at all four sites. Extensive survey work in the region over the past $4 \mathrm{yr}$ has resulted in only four individuals of $B a$ vayia goroensis being recorded, all from some form of maquis habitat. By contrast, B. septuiclavis is widespread in the region and has been recorded in both humid forest and a range of maquis habitats but is only infrequently encountered in open maquis, maquis arbustif, or Gymnostoma-dominated maquis. Indeed, these particular maquis habitats (in this region at least) have very low abundances of both skinks and geckos. 


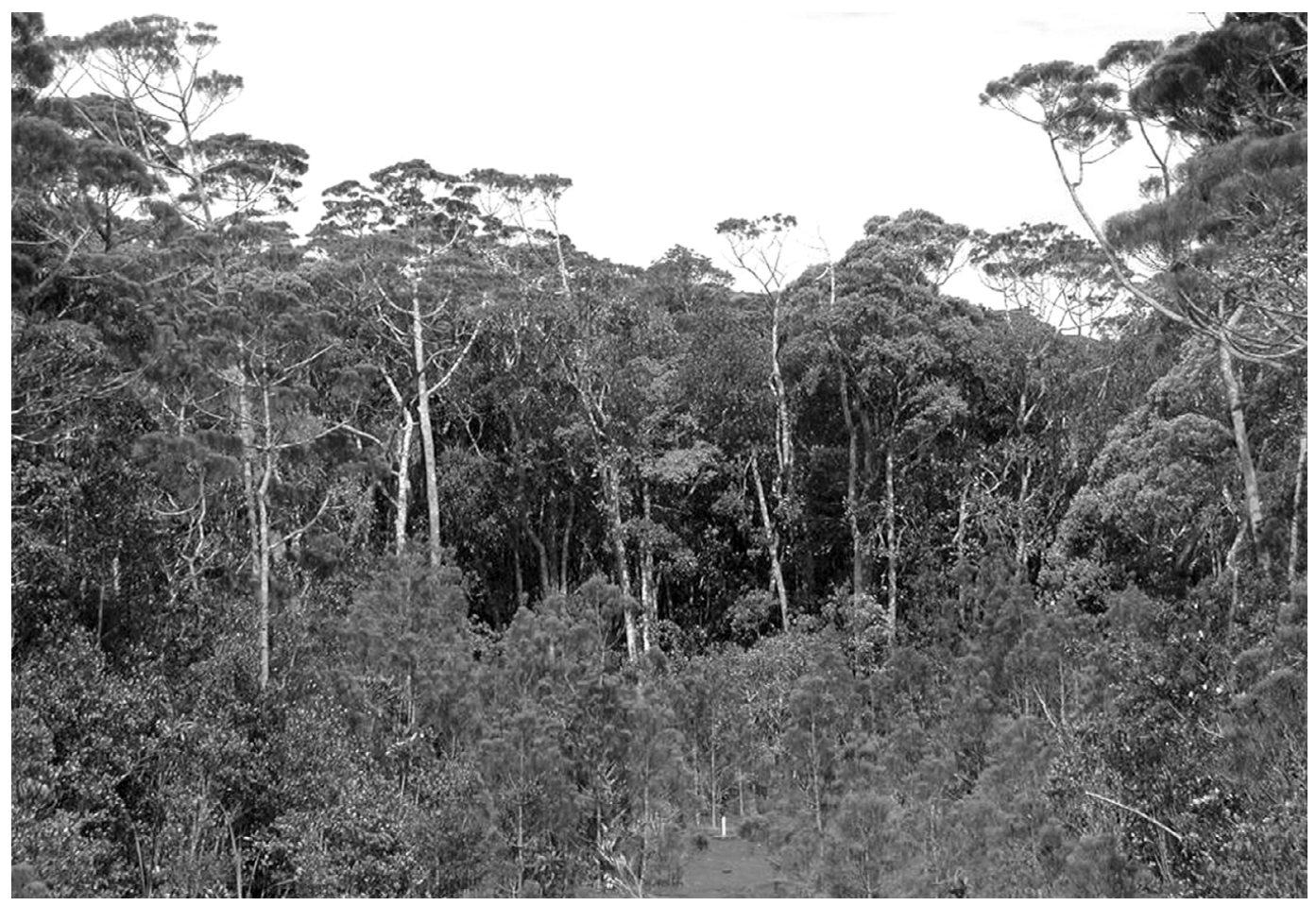

Figure 6. Maquis paraforestier at the type locality of Bavayia goroensis on the Plaine des Lacs, Province Sud, New Caledonia.

\section{Phylogeny}

In all analyses Bavayia goroensis is strongly supported as a member of the B. cyclura clade ( $95 \%$ bootstrap). Within this group it is the sister to an undescribed species from Mt. Ouin (100\% bootstrap) and together with that form it is basal to the remainder of the clade, including all described species previously allocated to the B. cyclura group (Bauer and Sadlier 2000, Wright et al. 2000), although this relationship does not receive strong bootstrap support (58\%).

\section{DISCUSSION}

\section{Conservation Status}

The species is known from two areas only 8$9 \mathrm{~km}$ apart. One of these is located on the Goro Plateau and both known collection sites in this area are within the proposed Goro nickel mine lease, lie within the long-term limits of the proposed extraction area, and will be subject in the short term to disturbance and visitation associated with proposed mine activity in the area.

Because of its limited distribution, clearly established threat to the habitat of one of the two known populations from proposed mining activities, and threat to maquis habitat in the region in general from fire, the species would be ranked as Endangered under a modified IUCN classification system (Sadlier and Bauer 2003) based on its area of occupancy $\left(<100 \mathrm{~km}^{2}\right)$, number of populations (two), and the apparent continuing decline in area, extent, and/or quality of habitat.

Extensive work in humid forest patches in the region has failed to record $B$. goroensis in this habitat and it seems that the species is a 
maquis endemic. It is difficult to assess the status of the species in the region because it is known from only a few records. Its occurrence in both open and canopied maquis indicates that it can occur across a range of maquis habitats, with a possible preference for dense or canopied maquis, as indicated by three of the four known specimens. Other areas of canopied maquis exist adjacent to the proposed area of mine activities and elsewhere in the region, but these have yet to be investigated. The distribution of the species may prove to be wider than the current information suggests, but, based on habitat availability and extensive survey work elsewhere in the Province Sud, it is unlikely to extend beyond the southern portion of the southern ultramafic block.

\section{ACKNOWLEDGMENTS}

We are grateful to the Province Sud authorities for supporting our herpetological research in southern New Caledonia and acknowledge in particular the support of Anne-Claire Goarant, Joseph Manaute (formerly of DRN), and Cendrine Meresse. Specimens of Bavayia goroensis were collected under permits 6034-5080 to AMBS and 6024-485/DENV/MT to WCL, both issued by DRN. We thank Jean-Michel N'Guyen of Goro Nickel (GNi) for logistical support and assistance throughout the contract work between AMBS and GNi. Further logistical support and encouragement were provided by Jean Chazeau and Hervé Jourdan of Institute de Recherche pour la Développement Nouméa. Michael Kiebish assisted in early stages of the molecular laboratory work.

\section{Literature Cited}

Bauer, A. M. 1990. Phylogenetic systematics and biogeography of the Carphodactylini (Reptilia: Gekkonidae). Bonn. Zool. Monogr. 30:1-219.

Bauer, A. M., and T. Jackman. 2006. Phylogeny and microendemism of the New Cale- donian lizard fauna. Pages 9-14 in M. Vences, J. Köhler, T. Ziegler, and W. Böhme, eds. Herpetologica Bonnensis II, Proceedings of the 13 th Ordinary General Meeting of the Societas Europeae Herpetologica. Zoologisches Forschungsmuseum Alexander Koenig, Bonn.

Bauer, A. M., T. Jackman, R. A. Sadlier, and A. H. Whitaker. 2006. A revision of the Bavayia validiclavis group (Squamata: Gekkota: Diplodactylidae), a clade of New Caledonian geckos exhibiting microendemism. Proc. Calif. Acad. Sci. 57:503547.

Bauer, A. M., and R. A. Sadlier. 1993. Systematics, biogeography and conservation of the lizards of New Caledonia. Biodiv. Lett. 1:107-122.

2000. The herpetofauna of New Caledonia. Society for the Study of Amphibians and Reptiles, Ithaca, New York.

Roux, J. 1913. Les reptiles de la NouvelleCalédonie et des Îles Loyalty. Pages 79160, pls. 4-5 in F. Sarasin and J. Roux, eds. Nova Caledonia, Zoologie. C. W. Kreidels Verlag, Wiesbaden.

Sadlier, R. A., and A. M. Bauer. 2003. Conservation status of endemic New Caledonian lizards-an assessment of the distribution and threats to the species of lizards endemic to New Caledonia [http://www.amonline.net.au/herpetology/ research/lizards_conservation_intro.htm].

Sadlier, R., and G. Shea. 2004. Étude faunistique spécifique herpétofaune sur le site minier Goro Nickel proposé. Report to Goro Nickel S.A., Australian Museum Business Service, Sydney. (Available from the authors.)

Swofford, D. L. 2002. PAUP*: Phylogenetic analysis using parsimony* (* and other methods), version 4.0. Sinauer Associates, Sunderland, Massachusetts.

Wright, J. L., A. M. Bauer, and R. A. Sadlier. 2000. Two new gecko species allied to $B a$ vayia sauvagii and Bavayia cyclura (Reptilia: Squamata: Diplodactylidae) from New Caledonia. Pac. Sci. 54:39-55. 